\title{
Wyzwolenie aktora, kolaże tekstowe i warstwy transhistoryczne. O teatrze Franka Castorfa
}

DOI: http://dx.doi.org/10.12775/LC.2018.014

Streszczenie: Artykuł zbiera najważniejsze cechy reżyserskiej twórczości Franka Castorfa, które kształtowały się najpierw we wschodnioniemieckich teatrach, a w pełni realizowały się przez ponad dwadzieścia lat w inscenizacjach berlińskiej Volksbühne am Rosa-Luxemburg-Platz. Na metodę reżyserską Castorfa składają się: koncepcja aktora jako performera roli, strategie dekonstrukcji materiału literackiego, nowoczesne koncepcje scenograficzne wykorzystujące media i konteksty popkulturowe, polityczność teatru. Autor tropi te cechy od najwcześniejszych realizacji, przez słynne, wielogodzinne inscenizacje Dostojewskiego, aż po najnowsze dzieło, Fausta.

Słowa kluczowe: Frank Castorf, teatr niemiecki, Volksbühne am Rosa-Luxemburg-Platz, auteur-director, transhistoryczność, kolaż teatralny

\section{Actor's liberation, text collages and transhistorical strata. On Frank Castorf's theatre}

\footnotetext{
Abstract: The article collects the most important features of the Frank Castor's theatre work, which developed first in East German theatres, and was fully realized for more than twenty years on the stage of Volskbühne am Rosa-Luxemburg-Platz in Berlin. Castorf's method of directing is composed

* Absolwent germanistyki i anglistyki na uniwersytecie w Lipsku, gdzie się doktoryzowal w 1994 roku; stypendysta Fulbrighta. Reżyser filmów dokumentalnych realizowanych na zamówienie telewizji MDR, NTV i 3sat. Juror Międzynarodowego Festiwalu Teatralnego „Kontakt”. E-mail: trirmer@aol.com.
} 
of: the concept of an actor as a performer, strategies of deconstruction of literary material, contemporary stage design using media and pop culture contexts, political theatre. The author traces these traits from the earliest realizations, through Dostoyevsky's famous long hours performances, to the latest work, Faust.

Keywords: Frank Castorf, German Theatre, Volksbühne, auteur-director, transhistoricality, theatrical collage

\section{Aktor wyzwolony}

M małym miasteczku w Niemieckiej Republice Demoluratycznej przy granicy z Polsk. W centrum znalazło się wyzwolenie aktora, który miał wprowadzić do roli rozpoznawalne elementy swojej osobowości i przez to - do inscenizacji osobiste akcenty interpretacyjne obejmujące obok wyuczonych konwencji także prywatne kryzysy. Chodziło przy tym o zerwanie z obiema głównymi liniami tradycji aktorskiej w NRD: ani Brechtowska koncepcja rozumiejącego (wiedzącego) aktora teatru epickiego, dysponującego efektem obcości, ani biegnąca od Stanisławskiego linia wczuwania się w całościową fikcyjną postać nie znalazły u Castorfa kontynuacji. Chodziło raczej o koncepcję aktora jako performera roli, co oznaczało w kulturowym kontekście ostatniej dekady NRD autentyczną bezpośredniość gry aktorskiej i przez to pozwalało ominąć ustandaryzowaną ramę teatru iluzji. Widz był zobligowany do włączania performatywnych ekscesów aktora w interpretację inscenizowanej sztuki. Nie chodziło przy tym o nową, zamkniętą interpretację, która cechowała w latach 70. niemiecki teatr reżyserii w NRD i RFN z jego przedstawieniami klasyki opartymi na dramaturgicznych poszukiwaniach i często także krytycznej recepcji. Zamiast tego otwierało się pole swobodnych asocjacji, skojarzeń z najbliższą teraźniejszością, pozwalające zerwać $\mathrm{z}$ tradycyjnym teatrem zaszyfrowanych znaczeń $\mathrm{w}$ warunkach cenzury i kontroli. Inscenizacja stawała się zdarzeniem, grą z tradycyjnymi konwencjami. Dla ukształtowania teatru Castorfa kontekst wschodnioniemiecki wydaje się bardzo ważny. Zwłaszcza że jego rozwój dokonał się w mało znaczącym prowincjonalnym teatrze, $\mathrm{z}$ aktorami w większości zaliczanymi do outsiderów w zawodzie. Warunkiem możliwości tej pracy było to, że Castorf jako główny reżyser (Oberspielleiter, mocna pozycja $\mathrm{w}$ niemieckim systemie teatralnym, poniżej intendanta) w znacznym stopniu sam mógł określać repertuar i skład zespołu. Wykorzystywał pozycję kierownika, którym został po kontrowersyjnych początkach w Brandenburgu w ramach swego rodzaju karnego zesłania. W Berlinie ten cały eksperyment nie byłby możliwy, ale w Anklam mógł Castorf pod okiem słabo wykształconych przedstawicieli władzy robić to, co chciał - mimo to doszło do wielu konfliktów. Wzory dla stworzonej przez siebie „bandy” aktorów odnalazł w Peterze Zadeku, który wciąż zaskakiwał i niepokoił teatr zachodnich Niemiec, i w Rainerze Wernerze Fassbinderze, którego niewiarygodna produktywność opierała się na mniej lub bardziej stałej grupie aktorów gotowych na każdą przygodę. Ten aspekt kolektywności sprzeciwiającej się estetycznemu konsensusowi nawet w sytuacji bez wyjścia, 
w każdym razie w miejscu bez perspektyw, wydaje się dla rozwoju estetyki teatru Castorfa nie do przecenienia.

W 1981 roku Frank Castorf napisał w książce Ernsta Schumachera, znanego eksperta od teatru Brechta w NRD i swojego nauczyciela z Uniwersytetu Humboldtów w Berlinie (w latach 1971-1976), następujące słowa:

W wielu teatrach [naszej] republiki można zauważyć ogólną tendencję redukowania aktora do jego mowy. To, że się tam jeszcze wlecze jakieś ciało, jest oczywiście odczuwane jako zło konieczne i traktowane po macoszemu. Kryje się tu z pewnością pewien brak, uwarunkowany również przez niemiecką tradycję aktorską i rejestrowany (nieświadomie) przez publiczność (Balitzki 1995: 32).

Oderwanie głowy od ciała aktora w niemieckiej tradycji teatralnej Castorf zauważył już jako student - wyprowadził z tego ideę wyzwolenia aktora, której realizacje można do dziś oglądać $\mathrm{w}$ Volksbühne oraz w licznych naśladowaniach. To z pewnością jeden $\mathrm{z}$ najważniejszych elementów jego wpływu na teatr końca XX wieku, idea łatwa do przeniesienia w podobne warunki w innych krajach.

\section{Reżyser jako autor}

Drugi ważny aspekt (po wyzwoleniu aktora-performera) to rola Castorfa jako autora inscenizacji. W czasie swoich studiów teatrologicznych zdobył oczywistą wtedy wiedzę o roli dramaturga w teatrze. Jego pierwszą pracą była ta właśnie posada w Senftenberg, w czasie kiedy dramaturg pełnił w niemieckim teatrze funkcję naukowego współpracownika zajmującego się artystycznym przygotowaniem przedstawienia, a później także jego realizacją w ramach zespołu reżyserskiego. Wiele przedstawień w latach 70. - na wschodzie i zachodzie Niemiec - opierało się na pracy przygotowawczej i potem współreżyserowaniu spektaklu przez dramaturga. Mistrzowie, tacy jak Peter Zadek, Peter Stein i Claus Peymann na Zachodzie czy Ruth Berghaus i Benno Besson w NRD, tworzyli przedstawienia, opierając się na wielkiej pracy dramaturgów. W tym kierunku Castorf został praktycznie wykształcony na studiach. Dlatego nie zaskakuje, że włączył te umiejętności w pracę reżyserską. Nowe z punktu widzenia codziennej praktyki teatralnej było połączenie tych ról.

O ile Castorf już w swych wczesnych pracach był reinterpretatorem, który wraz z aktorami zmieniał teksty oryginałów, o tyle wprowadzając teksty obce do inscenizacji, stopniowo stał się autorem, auteur-director, jak mówi francusko-angielski neologizm, chociaż to określenie ma mało wspólnego z ówczesną kulturą teatralną, gdyż zostało zapożyczone $\mathrm{z}$ kina. $\mathrm{Za}$ auteur-director można uznać $\mathrm{w}$ analogii do niemieckiego kina autorskiego lat 70. à la Werner Herzog i Fassbinder kogoś, kto opracował znany tekst we własny sposób. Za przykład można wziąć film Wima Wendersa i Petera Handkego Falsche Bewegung (Fatszywy ruch, 1975), który ukazywał w nowym świetle, przenosząc w teraźniejszość Republiki Federalnej Niemiec powieść Goethego Lata nauki Wilhelma Meistra. W latach 90. kolaż czy też zaskakujący montaż tekstów rozbijanych na fragmenty i na nowo powiązanych stały się specjalnością Castorfa. Metoda kombinacji i konfrontacji tekstów - szczególnie widoczna w zde- 
rzeniu Bitwy (Die Schlacht) Heinera Müllera z bulwarową sztuką Pension Schöller (1994) i Karla Grünberga Golden fließt der Stahl z Wolokolamsker Chausee Müllera (1996) - polegała na tym, żeby zasypać publiczność historycznymi warstwami i skojarzeniami z historią przemocy w XX wieku, otworzyć tekstom nowe przestrzenie skojarzeń. Transhistoryczne warstwy Rosji Dostojewskiego, Ameryki Tennessee Williamsa, fragmenty historii NRD i traumatycznej, niemieckiej teraźniejszości - to składowe polityczności Castorfa. Jeśli się cofnąć zupełnie do początku - groteskowe ujęcie niemieckiej traumy jest cechą zasadniczą jego twórczości: przełom (Wende) jako rana (Wunde) i surrealistyczny żart, który rozwinął się potem od połowy lat 90. - przede wszystkim w adaptacjach Dostojewskiego - w teatr filozoficzny.

\section{Partnerzy artystyczni}

Trzecim ważnym czynnikiem rozwoju języka teatralnego Castorfa są jego artystyczni partnerzy. W 1986 roku spotkał Berta Neumanna, absolwenta scenografii w Kunsthochschule Weißensee, najbardziej znaczącej uczelni w NRD kształcącej w tym zawodzie. W 1988 roku team Castorf/Neumann po raz pierwszy wystąpił razem. Inscenizacja Das trunkene Schiff (Statku pijanego), ballady Paula Zecha o Arturze Rimbaudzie, zrealizowana po przybyciu Castorfa z prowincji do Volksbühne w Berlinie, stała się równocześnie sygnaturą wszystkiego, co miało nadejść i od 1992 roku zmienić teatr w nowych Niemczech na znów świeży i bezczelnie zaangażowany. Neumann zwęził już i tak wąską przestrzeń na drugim piętrze Volksbühne do rozmiarów klitki z niewielką liczbą rzędów - Henry Hübchen mógł praktycznie wejść na głowę widzom. W dodatku ta przestrzeń była surrealistyczną jaskinią gry - z fortepianem, który w połowie wystawał z niebieskiej ściany, i oknami zasłoniętymi zwykłym papierem pakowym, oświetloną światłem neonówek. To było fantastyczne czarowało mało szlachetnymi składnikami, takimi jak zwyczajne, sklepowe jarzeniówki, które później we wciąż nowych wariacjach można będzie zobaczyć w produkcjach duetu Castorf/Neumann.

Bert Neumann, urodzony w 1960 roku w Magdeburgu, dorastający we wschodnim Berlinie, studiowal, jak już była mowa, scenografię w Kunsthochschule Weißensee w pierwszej połowie lat 80 ., kiedy przestrzenie teatralne konstruowano za pomocą kulis z papier-mâché i ustawionych na scenie mebli z teatralnych magazynów. Tego rzemiosła nie dało się już sensownie ulepszyć i właśnie dlatego mała grupa absolwentów szkoły w Weißensee w tym koledzy i późniejsi partnerzy Castorfa: Hartmut Meyer i Peter Schubert - zdystansowała się gwałtownie i pomysłowo od tych konwencji. Neumann wprowadzał w przestrzenie sceniczne realia odchodzącego wtedy w przeszłość świata, tak aby to, co konkretne, mogło się objawić w wymiarze surrealistycznym, często nawet magicznym. Na przykład niezapomniany terkoczący warsztat tkacki w Tkaczach Gerharta Hauptmanna w centrum spektaklu ujmującego sztukę niemieckiego noblisty zupełnie niehistorycznie, jako obraz szczytu masowego bezrobocia w 1997 roku. Albo plastikowe meble ogrodowe, które rozlatywaty się pod wieloma postaciami z powieści Dostojewskiego i Bułhakowa. Do historii przejdą wynalezione przez Neumanna (ściślej: znalezione w rzeczywistości) kontenery. Proste, balansujące między marną estetyką bungalowu i improwizowanego życia, dały Castorfowi 
w jego wielkich inscenizacjach pretekst i później nie zawsze trafnie naśladowane usprawiedliwienie, aby filmować aktorów na żywo we wnętrzach. W ramach nowego połączenia kina i teatru reżyser wprowadził zbliżenie jako „okno” powiększające w świecie scenicznym. $\mathrm{Na}$ jego potrzeby Jan Speckenbach wymyślił technikę wideo, która rozwinęła się od powiększonego pojedynczego obrazu do pełnego filmu rejestrowanego dwiema kamerami, montowanego na żywo i transmitowanego na ekrany.

Kontener stał się rozpoznawalnym niemal na całym świecie znakiem Neumanna, mimo to wieloletni scenograf Volksbühne wciąż zaskakiwał. W 1999 roku zbudował na potrzeby cyklu Szekspirowskiego z surowego drewna na berlińskim Praterze teatr „Globe”, w którym widzowie z lóż spoglądali na małą arenę, mając w zasięgu ręki wydanie Kapitału Marksa wiszące na toaletowym łańcuszku. Były także pewne drobiazgi, które Neumann wniósł do wspólnego dzieła, czegoś w rodzaju Gesamtkunstwerk, Volksbühne. Prawie każdy berliński bywalec teatru mógł zaopatrzyć się w zaprojektowane przez Neumanna pudełka zapałek, których etykiety zawsze stanowily krótki komentarz na temat teraźniejszości. Ostatnio, kiedy era Castorfa miała być przez polityków brutalnie zakończona, pojawiła się edycja zapałek z napisem „Game over”. Neumann musiał być bardzo rozgoryczony, skoro powiedział, że wolałby otworzyć studio tatuażu, niż pracować u następcy Castorfa w Volksbühne. $\mathrm{Na}$ banerze na frontonie teatru, jednym z kolejnych wynalazków Neumanna, nie tylko widocznym z daleka, ale także dającym się dobrze odczytać ze szczytu słynnej wieży telewizyjnej, scenograf umieścił w czerwcu 2015 roku, kiedy już sprawa odejścia Castorfa była przesądzona, napis wielkimi literami: VERKAUFT (Sprzedane) ${ }^{1}$.

\section{Wyprawa do Brazylii (2007)}

W 2005 roku w Volksbühne gościł Teatro Oficina teatralnego kapłana Ze Celso (José Celso Martinez Correa), aby zaprezentować tropikalnie wybujałą historię prowincji Sertao podczas czterech wieczorów jako totalny teatr wszelakich form i środków. Było to ekstatyczne zniesienie granic, które zainspirowało Castorfa do spotkania z takim samym lub podobnym zjawiskiem w Brazylii. Współpracując z brazylijskimi artystami, Castorf mógł oddać największą przysługę nieodkrytemu jeszcze w Europie dramatopisarzowi Nelsonowi Rodriguesowi, który w Brazylii mimo swojej ekstremalnej postawy estetycznej, społecznej i politycznej uchodzi już za narodowego klasyka. Urodzony w 1912 roku Rodrigues był przede wszystkim oryginalnym dziennikarzem, zanim zaczął w latach 40. pisać dramaty w ramach zacofanej i oddalonej od reszty świata kultury teatralnej. Stał się prekursorem współczesnej dramaturgii brazylijskiej będącej mieszanką językowego naturalizmu i surrealizmu. Nastawiony na kulturę klasy średniej atakował specyficznie brazylijską idealizację harmonii rasowej i rodzinnej za pomocą naładowanych seksualną przemocą ballad. Teatrowi odczuwanemu jako czysta rozrywka odpowiadał: „Aby zatrzymać publiczność, trzeba zaludnić scenę mordercami, cudzołożnikami i wariatami, krótko mówiąc - zgrają potworów”. Na powierzchni chodziło Rodriguesowi o efekty szokowe, w głębi o dramat, któ-

\footnotetext{
1 Warto wspomnieć o dwóch jeszcze ważnych partnerach Franka Castorfa: kanadyjskim kompozytorze i muzyku Sir Henry oraz - w ostatnich latach - serbskim scenografie Aleksandarze Deniciu.
} 
ry naprawdę porusza społeczeństwo. Publiczność, która pozostaje nieporuszona, uważał za niewartą uwagi. Po tym, jak w 1943 roku w Sao Paolo amatorska grupa Os Comediantes pod kierunkiem polskiego emigranta Zbigniewa Ziembińskiego wystawiła jego pierwszą sztukę Vestido de noiva (Suknia ślubna), mógł być pewny swego. Rasowo i społecznie zawikłane historie seksu i kazirodztwa, kojarzące się z antycznymi mitami, okazały się wyjątkowe bliskie jego publiczności. Aplauz odrzucał jako nieporozumienie. Zwłaszcza ze strony tych, którzy widzieli w nim pierwszego, modernistycznego dramatopisarza Brazylii. Modernizm uważał za elitarny, jeśli nawet w jego sztukach pojawiały się niezwyczajne przeskoki czasowe, ekstremalnie konturowane strumienie świadomości i tzw. figury epickiego teatru postbrechtowskiego. Publiczność dopingował nieustannie za pomocą cytatów. Zawsze pojawiały się u niego fascynujące i przerażające postaci, nie idee.

To właśnie szczególnie interesowało Castorfa. Z dobrego tuzina sztuk Rodriguesa wybrał napisanego w 1946 roku Czarnego anioła (Anjo Negro) i zmontował go z fragmentami dramatu Heinera Müllera Zlecenie. Wspomnienie o rewolucji (Der Auftrag. Erinnerung an eine Revolution), który dotyczy możliwości i niemożliwości rewolucji w Ameryce Łacińskiej. Castorf zderzył dwie różne materie: pesymistyczny tekst Müllera, gdyż autor zrezygnował w nim z oczekiwania na nową rewolucję jako katalizator przemiany przegranej lewicy na Zachodzie i skostniałego komunizmu na Wschodzie, z dramatem Rodriguesa o odczarowaniu harmonii ras w Brazylii.

W Czarnym aniele stają naprzeciw siebie biała Virginia i czarny Ismael w brutalnym mezaliansie, w którym chodzi o dziedziczenie koloru skóry i jego społeczne czy nawet archaiczne postrzeganie. Virginia zabija spłodzonych w małżeństwie z Ismaelem, poczętych w wyniku gwałtu, czarnych synów. Z Eliasem, białym pół-bratem Ismaela (bratem z sierocińca?), Virginia ma córką Anę Marię, którą Ismael oślepia, aby już nigdy nie zobaczyła jego koloru skóry i żadnego innego mężczyzny. W finale Ismael ją utopi. W tym czasie Virginia nosi już w brzuchu kolejnego czarnego anioła - wszystko więc wiecznie się powtarza, dramat przekształca w rytuał. Rodrigues stworzył swoją sztukę - podobnie jak Jean Genet jako bezlitosny, okrutny rytuał, w którym pożądania między czarnymi i białymi oddziałują fatalnie i autodestrukcyjnie. Nie ma prawdopodobnie bardziej pesymistycznego spojrzenia na brazylijską harmonię kolorów skóry - na tę utopię swoistego wytańczenia (wegtanzen) i wymarzenia (fortträumen) kolonialno-niewolniczej przeszłości.

Zlecenie (Der Auftrag) Heinera Müllera jest natomiast spojrzeniem na przeszłość, w której społecznie ugruntowany rasizm również rozkłada ideały rewolucji francuskiej. W tercecie wysłanych z Paryża na Karaiby emisariuszy rewolucji znajdują się chłop Galloudec i mieszczanin Debuisson - przeciwstawieni czarnemu Sasportasowi, który nie posiada ani dobytku, ani ojczyzny i historycznie mógłby być nieuprzywilejowanym, bezdomnym Brazylijczykiem. Prawie mieszkańcem faweli w Sao Paulo, gdzie gigantyczny obszar nie-miasta rządzi się własnymi prawami, które wyciskają piętno na ich poczuciu własnej wartości - rodzą nienawiść do samych siebie (Selbst-Hass), ale także energię terrorystyczną. To jest właśnie punkt, do którego Castorf prowadzi oba teksty. Czarny anioł ze zleceniem.

Bert Neumann zbudował scenę przypominającą niedbale zbite gwoździami tekturowe ściany fawel. Można je zerwać, aby uczynić widzialnym niekoniecznie piękniejszy świat taniego baru. Najmocniejszy moment, w sensie przestrzennym i metaforycznym, to jednak obraz stojącego z tyłu sceny zwyczajnego kontenera, wewnątrz którego kamera filmuje bohaterki sztuki wciąż walące młotkami w ściany. Są one pełne zwątpienia, uwięzione. Zapis 
wideo to obraz strachu. Po krótkiej ekspozycji na ekranie pojawia się Mann im Fahrstuhl (Mężczyzna na wózku) Heinera Müllera, koszmar senny europejskiego urzędnika, który leci do szefa w Peru, a więc wysiada w Trzecim Świecie. Castorf wprowadza tu osobliwe, trudne do zidentyfikowania undergroundowe dźwięki składające się z odgłosów dżungli i hałasu maszyn jako naprawdę niepokojących elementów akustycznych. Potem pojawia się sen o Nowym Jorku i staje się jasne, że Castorf cytuje Müllera w nowym, współczesnym kontekście, tak jak tego wymagają jego teksty. Rozpaczliwie, otwarcie.

Reżyser zmienił jednakże tradycyjne brazylijskie konwencje obsady ról. Postaci czarnych bohaterów obsadził białymi aktorami i na odwrót białych - czarnymi. W wymiarze egzystencjalnie naznaczonych kolorów skóry spektakl wydarza się więc w lustrzanym odbiciu. Virginię gra uwolniona od wszelkich białych strachów Denise Assuncao. W Ismaela wciela się z cudownym dystansem Roberto Audio. Nie ma tu rasowej klaunady czy nawet minstrel show. Ale też nie ma konwencji, w której grywa się zwykle inscenizacje dramatów Rodriguesa w teatrze. Prawie wszyscy noszą blond peruki, jakie często pojawiają się w brazylijskich reklamach i sugerują, że białe blondynki w świecie towarów są najbardziej reprezentacyjne. $\mathrm{W}$ tym sensie Czarny anioł Castorfa stanowi coś w rodzaju otchłani samby, niepewnych przypisań koloru skóry i psychiki w połączeniu z tekstami Heinera Müllera.

\section{Kean / Hamletmaschine - kolejny kolaż z tekstem Heinera Müllera (2008)}

Szekspirowski aktor Edmund Kean (1787-1833) zainspirował swoim pełnym przygód życiem między rampą a salonem francuskiego romantyka Aleksandra Dumasa ojca do napisania sztuki z jego nazwiskiem w tytule. Dramatu o artyście rozdartym, jak głosi podtytuł, pomiędzy „nieporządkiem i geniuszem”, zupełnie zapomnianym, dopóki Jean-Paul Sartre w 1954 roku nie zwrócił w swojej adaptacji uwagi na wartościowe ujęcie losu outsidera (co zainspirowało $\mathrm{z}$ kolei dramatopisarza Lothara Trolle do napisania adaptacji dla Castorfa). Edmund Kean był aktorem, którego ludzie koniecznie chcieli zobaczyć także dlatego, że jego życie stanowiło wzór dla rozmaitych fantazji o awansie. Naturalny talent dosłownie z rynsztoka awansował do rangi gwiazdy teatru, obracającej się w wytwornych kręgach i równocześnie działającej przeciw aroganckiej arystokracji w założonym przez siebie „Klubie Wilków”. Interesujący przykład społecznej schizofrenii. Publiczność tak samo hołdowała prywatnym ekscesom Keana, jak jego rolom szekspirowskim. Sztuka Dumasa sytuuje się właściwie daleko poza polem zainteresowań Castorfa. Opowiada o trzech romansach Keana i związanych z nimi intrygach. W tym o najważniejszej relacji z żoną duńskiego ambasadora hrabiego Koefelda, Eleną, podczas gdy aktor staje w obronie wrażliwej Anny Damby, która została wytypowana przez wyższe sfery na ofiarę. Również w miłości Kean jest rozdarty, zupełnie według wzorów francuskiego romantyzmu, gdzie nic nie jest bardziej pikantne niż chytre stawianie oporu stojącym wyżej w hierarchii społecznej.

Castorf wie oczywiście, że takiej sztuki nie inscenizuje się z wielkim rozmachem, lecz pozwala działać pospiesznie naszkicowanemu przedstawieniu. Hartmut Meyer dostosował do tego scenografię wyglądającą jak nieco zwinięty kort tenisowy albo zielona tape- 
ta, która spadła ze ściany. Z prawej widać opuszczane z masztu flagi brytyjską i duńską, jakby wszystkie te, jedna za drugą rozwijane intrygi były rodzajem zawodów sportowych pokrytych dyplomatyczną warstewką. Niezbędne dla intryg meble, takie jak łóżka i szafy, są rozstawiane jak na próbie teatralnej na korcie tenisowym, wszystko wygląda lekko i niezupełnie poważnie. Gitarzysta Steve Binetti podkreśla swoimi improwizacjami to ogólne wrażenie. Trzyipółgodzinny wieczór składa się w sześćdziesięciu procentach z porywającego Alexandra Scheera, w 20 - z pustego przebiegu intryg i w kolejnych 20 - z genialnej idei Castorfa. Trzykrotnie reżyser przełącza się z Dumasa na Hamletmaschine Heinera Müllera jako zupełnie zaskakujące źródło odniesienia. Najpierw pijany Kean wpada w słynny monolog „Ich war Hamlet und redete mit der Brandung blablabla” („Byłem Hamletem i rozmawiałem z kipielą, ble ble ble"), zestawiony z komentarzami o apokaliptycznym Heinerze Müllerze - hommage z okazji jego osiemdziesiątych urodzin. Później mistrz nadzoruje oddane mu uczennice przy pracy nad pierwszym monologiem Ofelii. To jest oczywiście Kean-Szekspir, który w końcu chciałby wydostać się z gorsetu Szekspira, mówiąc „prywatnymi” słowami Müllera, dającymi m.in. świadectwo schizofrenii intelektualisty-buntownika. Pod koniec - dla Keana, który wkrótce zostanie przywiązany drutem kolczastym do krzyża, świat salonu staje się więzieniem - pół zespołu brnie przez trzy małe, chwiejące się, kartonowe chaty, wypowiadając wielki „monolog obrzydzenia” z czwartej części. „Mój dramat, gdyby jeszcze miał się wydarzyć, miałby miejsce w czasie powstania”. Za pomocą tej komicznej daremności Castorf czyni z rekina popkultury płotkę. Tego rodzaju konfrontacje tekstów Müllera ze stosunkowo banalnymi kontekstami i z użyciem środków wodewilu były w tym czasie autorskim gatunkiem Castorfa.

\section{Groteskowy Czechow w Moskwie (2010)}

„Co za niespokojna noc!”. Kiedy to zdanie pada po dwóch i pół godzinach, krótko przed antraktem w Teatrze Mossowjetu, na scenie rozlegają się owacje. Autokomentarz Franka Castorfa do jego interpretacji Trzech sióstr na otwarcie Międzynarodowego Festiwalu Czechowa dotyczy znanego świata córek generała, które mieszkając na prowincji, tęsknią za Moskwą. Castorf wmontował w tę inscenizację także mniej znane, mroczne opowiadania Czechowa. Opowiadanie Chłopi mówi o powrocie pewnej rodziny do zrujnowanej wioski, po tym, jak ojciec na skutek choroby musiał zrezygnować z pracy kelnera w hotelu Słowiański Bazar, a życie w mieście stało się nazbyt drogie. Krótko mówiąc: jedni tęsknią zawsze za Moskwą, drudzy właśnie stamtąd przybywają. Pierwsi przyjmują w salonie oficerów, drudzy lądują w kręgu wiejskiego lumpenproletariatu. W obu historiach pojawia się jako katastroficzne tło nocny pożar.

Scenografia Berta Neumanna sytuuje oba miejsca gry obok siebie: z prawej, trochę wyżej, zabudowaną werandę, z lewej rozlatujący się drewniany domek, z którego transmitowane są bezpośrednio na LED-owy ekran grubiańskie czyny „mużyka”. A ponad tym lub z tyłu piękny rosyjski las brzozowy. Nie tak jak swego czasu u Petera Steina prawie naturalny, lecz można powiedzieć prostacki, powieszony na plandece. Zgodnie z oczekiwaniami Castorf przeciwstawia się historii recepcji, szczególnie długiemu oddziaływaniu reżysera prapremiery Konstantego Stanisławskiego, którego psychologiczne wczucie w pełne po- 
staci stanowi absolutne przeciwieństwo metody aktorskiej Castorfa. Reżyser powiedział nawet, że Czechow został przez recepcję Stanisławskiego zafałszowany - Czechowowskie postaci osadzone w grotesce i zagrane z pewną krzykliwością poprowadziłyby raczej ku teatrowi Artauda, zamiast utonąć w uczuciowej skardze i tęsknocie.

Napięcie wzrasta, gdy akcja przenosi się z salonu do rynsztoka. Tam wieczór otrzymuje swoją tezę rodem z Heinera Müllera: „To, że Marks i Engels wyłączyli lumpenproletariat z ruchu rewolucyjnego, stało się podstawą stalinowskiej perwersji”. Takie twierdzenie wypowiedziane w Moskwie wydaje się śmiałe i w dodatku trochę anachroniczne, ponieważ jedynym ruchem rewolucyjnym jest dzisiaj kapitał i to wyłącza lumpenproletariat bez konieczności podejmowania decyzji. Dla publiczności taka pigułka była dużym zaskoczeniem, a dla organizatorów festiwalu właśnie tym, czego oczekiwali od Castorfa. Walerij Szadrin, dyrektor festiwalu Czechowa, wyraźnie życzył sobie nowego spojrzenia na rosyjskiego klasyka, „innego rozumienia jego dzieła w kontekście współczesnych doświadczeń”. Krzykliwość, groteska, które Castorf odkrył w Czechowie, zmontowane z cytatem z Müllera - to jest w produktywnym znaczeniu brutalna konstrukcja i rzeczywiście nowe spojrzenie na Czechowa. W inscenizacjach jego dramatów zawsze dominował ton salonowy, a kontekst jego ekstremalnych opowiadań (np. Sali numer sześć) czy książki o łagrach na Sachalinie bywał zwykle przemilczany. Czechow jako lekarz pozostawał nie tylko analitykiem duszy, lecz także sarkastą aspołeczności - tę komplementarność Castorf dobrze rozpoznał.

Tylko w rosyjskim wydaniu dzieł zebranych Czechowa znalazła się rozszerzona wersja opowiadania, w której wdowa z małoletnią córką Saszą (Maria Kwiatkowski) wraca jako prostytutka do Moskwy. Castorf umieszcza to „uzupełnienie” w wymyślonym czwartym akcie - i w ten sposób wchodzi w teraźniejszość. Castorf nie tylko czyni skomplikowanym montaż tekstów, lecz także nasyca inscenizację wizualnie niezliczonymi cytatami i aluzjami. Ikoniczne obrazy propagandy sowieckiej, Andriej spychający wózek dziecięcy wciąż od nowa ze schodów werandy jako przywołanie słynnej sceny z Eisensteinowskiego Pancernika Potiomkina stanowią kontynuację idei transhistoryczności.

\section{Apocalypse Baal w Monachium (2015)}

To przedstawienie nie tylko przejdzie do historii teatru. Jako przedmiot sporu o prawa autorskie trafiło też do sądu. Spór dotyczył kwestii podstawowej w niemieckim teatrze reżyserii, mianowicie pytania o to, co jest bardziej warte ochrony: prawo autora, które w określonym stopniu chroni pojedyncze dzieło, czy praktyka teatru, w którym pojedynczy dramat jest inscenizowany jako radykalnie nowa interpretacja. W wypadku zrealizowanej przez Castorfa wersji Baala sprawa jest jeszcze bardziej skomplikowana. Dlatego że nie można mówić o jednym dziele Brechta, gdyż autor przerabiał swój debiut z 1918 roku nie mniej niż cztery razy. Kiedy Brecht w 1954 roku po raz ostatni podjął się przygotowania Baala do edycji wczesnych dramatów, zauważył: „Przyznaję (i ostrzegam): temu dramatowi brakuje mądrości”. Dla Castorfa to zdanie było dobrym pretekstem, aby poszukać za pomocą tej sztuki innej mądrości we współczesnym świecie. Nie można było od niego oczekiwać Baala jako tylko antymieszczańskiego poety i bekającego uwodziciela sprzed stu lat, zwłaszcza że 
reżyser jest znany z tekstowych montaży i wędrówek transhistorycznych przez różne obszary geograficzne i ery polityczne.

Główna idea polegała na połączeniu Baala Brechta z filmem Francisa Forda Coppoli Czas apokalipsy (1979), a więc przeniesieniu głodnego życia indywidualisty w czasy wojny w Wietnamie, wysłaniu na wycieczkę do piekła bardziej współczesnej historii. Oczywiście nie jako czysta adaptacja czyniąca z Baala kapitana Willarda, który w dżungli ma zabić zbuntowanego pułkownika Kurtza granego w filmie przez Marlona Brando. Chodziło raczej o zanurzenie się i zatracenie $\mathrm{w}$ dżungli, którą można kojarzyć z Brechtowskim motywem lasu. Zostały równocześnie zderzone dwa kierunki interpretacyjne: problem uwolnienia jednostki na wojnie z żądzami i ekscesami Baala, a także dobrze rozpoznawalny temat wojen (post)kolonialnych, na który Castorf zwraca uwagę poprzez całą serię akcentów francuskich. Grany przez Aurela Mantheia Baal jest właściwie także Francuzem i pojawia się w długiej scenie z reżyserskiej wersji Apocalypse Now Redux u francuskich właścicieli plantacji, którzy bronią Indochin jako swojej ojczyzny. Wcześniej można usłyszeć francuską wersję Hey, Joe Jimiego Hendriksa i nie jest trudno odkryć, chociaż prawie o tym zapomnieliśmy, francuskie podłoże wojny Amerykanów w Wietnamie. Premiera w monachijskim Residenztheater odbyła się kilka dni po ataku na redakcję „Charlie Hebdo” w Paryżu i zyskała dzięki temu realny kontekst zwalniający z podejrzeń, że reżyser w całkiem abstrakcyjny sposób połączył Baala i Czas apokalipsy.

Dramat Brechta został na potrzeby tej realizacji mocno przerobiony. Wiele postaci kobiecych zostało połączonych w jednej Sophie, a w „Isabelle, piekielnej małżonce” powstała nowa figura, która tworzy wraz z Baalem i Ekartem (Franz Pätzold) infernalne trio w czteroipółgodzinnym spektaklu. Baal Brechta jako opadająca linia mieszczańskiej uczty dla poety aż po mord na Ekarcie i zniknięcie w lesie został tu przekształcony w asocjacyjny „zygzak” w dżungli, który można rozumieć metaforycznie jako „heart of darkness” zachodniego świata. Obok tekstów z Baala została wprowadzona podróż rzeką Kongo Josepha Conrada jako inspiracja dla Czasu apokalipsy połączona z wierszami Brechta i Rimbauda oraz tekstami Frantza Fanona i Ernsta Jüngera. Wtargnięcie do puszczy jako podbój kolonialny oraz kolektywne i indywidualne samopoznanie - to spaja Castorfowskie zawłaszczenie Baala w kompleksowym, pełnym sprzeczności spektaklu. O ile Baal Brechta wędrował przez prawdziwie prowincjonalny świat outsiderów, o tyle Castorf poprzez swoje transhistoryczne przesunięcie przeniósł go w konkretny, pełen asocjacji kontekst historyczny.

Aby to wszystko mogło ukazać się w zmysłowych obrazach na deskach teatru, Aleksandar Denić stworzył na scenie obrotowej jedną ze swoich masywnych i bogatych $\mathrm{w}$ detale scenografii. $\mathrm{W}$ centrum znalazł się rodzaj pagody z wnętrzem przystosowanym do transmisji na żywo, na skraju dominował jednak prawdziwy amerykański śmigłowiec, taki jaki naznaczył ikonograficznie niczym monstrualny insekt obrazy konfliktu w Wietnamie. Ze względu na warunki wojny w dżungli ten śmigłowiec stał się swego rodzaju powietrznym czołgiem - to dlatego Coppola zdecydował się na ukazanie w legendarnej scenie filmu baletu śmigłowców przy akompaniamencie Cwału Walkirii Richarda Wagnera. Pod koniec wojny, po upadku Sajgonu, takie śmigłowce zrzucano z lotniskowca do morza, aby można było ewakuować do domu ostatnich amerykańskich żołnierzy. Te wyryte w pamięci obrazy wykorzystał serbski scenograf, znany ze współpracy z Emirem Kusturicą przy filmie Underground. Denić mówi nawet, że praca u Castorfa umożliwia idealne połączenie scenografii teatralnej z filmową. Sposób ustawienia śmigłowca naprzeciw pagody i wyobrażonej 
dżungli, a potem jako wnętrza, w którym kończy się ostatecznie akcja Baala, gdy spala się infernalne trio, stanowi ikonograficzny majstersztyk, który na długo pozostanie w historii teatru.

Baal nie jest u Castorfa Brechtowskim artystą, lecz rzuconym w świat, uzdolnionym i pełnym żądz outsiderem, który jednak wspaniale pasuje do tego świata, gdyż nie ma w nim żadnego porządku oprócz komentującej piekielnej małżonki. Postaci przejętej z tekstów Rimbauda, którego Castorf umieścił w swoim teatralnym debiucie w Berlinie Wschodnim, Statku pijanym Paula Zecha, jako poetę - wizjonera ginącej wciąż w XX wieku Komuny Paryskiej z 1871 roku i utożsamił z Jimem Morrisonem. Po dziesięcioleciach koło zamyka się w zupełnie innym świecie, który właśnie inicjuje na nowo proces przemyślenia skutków kolonializmu po imperialnym XX wieku i w erze współczesnych terroryzmów. Po decyzji sądu Castorf mógł pokazać Baala tylko raz w Monachium i ostatni raz w Berlinie - wolność techniki kolażu została podważona akurat przez córkę Brechta, specjalisty od przeróbek i przetworzeń.

\section{Zasada nadrywu i przenikanie przeszłości w teraźniejszość: \\ Bracia Karamazow transhistorycznie w Berlinie i Szwejk w Monachium $(2015 / 2016)$}

Na potrzeby inscenizacji Braci Karamazow w Berlinie Neumann zupełnie przemeblował dużą salę Volksbühne. Na ścianach ciemna lameta, z przodu rosyjski blok z czarnym bajorem i minipawilonem, z lewej wielki drewniany twór, w którym coś w rodzaju sauny wypuszcza parę. Publiczność siedzi na wielkich workowych kanapach rozłożonych na antypoślizgowym asfalcie. Aktorzy grają także do kamer, w różnych zewnętrznych przestrzeniach aż po dach teatru. Trzynaście lat wcześniej wymieniany wciąż jako najważniejszy partner Castorfa scenograf już raz przebudował Volksbühne w totalną przestrzeń na potrzeby inscenizacji Idioty Dostojewskiego. Publiczność mogła poruszać się po wielopiętrowej scenie obrotowej i oglądać „Neustadt” z jego spelunkami, sklepami i mieszkaniami, które tworzyły razem zaskakującą panoramę. Spojrzenie widza było wciąż prowokowane, ponieważ wokół znajdowało się jeszcze kilka monitorów pokazujących obrazy transmitowane na żywo. Ten podwójny teatr widzenia na pozbawionej granic widowni stanowil punkt szczytowy hybrydyzacji kina i teatru.

Sześciogodzinne przedstawienie to siódma inscenizacja Dostojewskiego zrealizowana przez Castorfa, summa rosyjskiego powieściopisarza $\mathrm{z}$ typową dla niego tematyką Wschodu-Zachodu, wolności-ortodoksji, miłości-chaosu. Pierwsza dwuipółgodzinna część funkcjonuje jako wydłużona, ale klarowna ekspozycja prezentująca postaci i niezbyt obszerną akcję skoncentrowaną wokół zabójstwa ojca na rosyjskiej prowincji. Hendrik 
Arnst, „partyzant” Castorfa jeszcze z okresu pracy w Anklam, gra tego ojca Fiodora jako zaszczutego bywalca, który na dystans trzyma synów Dmitrija (Marc Hosemann), Iwana (Alexander Scheer) i zupełnie nietypowego, niczym jędrny Bachus, korpulentnego Aleksieja (Daniel Zillmann) oraz swego syna z nieprawego łoża Smerdiakowa jako sługę (Sophie Rois). Do aktywności w dosłownym sensie skłaniają ich dopiero kobiety - Kathrin Angerer jako Gruszeńka, Lilith Stangenberg jako Katerina Iwanowna i Margarita Breitkreiz jako Lizawieta Smerdiaszczaja. Jeanne Balibar z przerzedzonymi włosami i trupią twarzą wciela się, właściwie tylko leżąc, w najważniejszą figurę religijną, starca Zosimę. Nastrój jest mroczny, wszyscy są przed kamerą mniej lub bardziej podnieceni (ale obywa się bez scen slapstickowych), od czasu do czasu Castorf pozwala przenieść się w niedawną przeszłość Rosji z orgiami chuliganów i przeżywanym przez całkowicie zdezorientowaną młodzież postsowieckim rozkładem. Poprzez to połączenie opuszczonych przez Boga postaci z czasami absolutnego ateizmu (po ateistycznym komunizmie) ustanawia Castorf najważniejszą linię dramaturgii. Warto zapoznać się chociaż pobieżnie z książką Piotra Silajewa (DJ-a Stalingrad) Exodus, aby zrozumieć ten tranhistorycznie inspirujący ciąg wywiedziony $\mathrm{z}$ ducha Dostojewskiego.

Drugą część otwiera wyrastający w tym spektaklu ponad siebie Alexander Scheer $\mathrm{z}$ Legendą o Wielkim Inkwizytorze filmowaną na dachu teatru przy słynnym neonie z napisem OST, ponad dachami Berlina. Już to stanowi najpiękniejsze i paraliżujące przekroczenie: swoiste przesłanie tego właśnie tekstu do współczesnego świata. Niewierzący Iwan Scheera ma jeszcze potem długą scenę z obrazem Hansa Holbeina Chrystus w grobie - kto właściwie umarł?

Tuż po wielkiej mszy na dachu pada z ust Balibar w roli Chochlakowej kluczowe pojęcie: nadryw. Wielka tłumaczka Dostojewskiego na język niemiecki, Swietłana Geier, na której przekładach opierają się prawie wszystkie wcześniejsze inscenizacje Castorfa, zdecydowała się w wypadku Braci Karamazow nie tłumaczyć tego słowa i przez to wprowadzić je do języka niemieckiego. To pojęcie awansuje u Castorfa do rangi terminu nadrzędnego i określającego także styl gry aktorskiej - a nawet obecny stan teatru Volksbühne: załamania psychiczne, kontrolowana egzaltacja, pełen oczekiwań strach egzystencjalny - wszystko to obejmuje pojęcie nadrywu i wszystko to można w tym spektaklu porywająco przeżyć. „Bez Boga nic nie jest dozwolone. Pozostaje już tylko strach” - oznajmia Sophie Rois. Do tej realności dołącza to, co wyobraża sobie Alosza, uczeń Boga, dla którego Castorf i Neumann stworzyli niczym quasi-ikonę kuszący obraz młodego Stalina, prawdopodobnie zbiegłego właśnie z seminarium, aby rozpocząć terrorystyczną agitację.

Trochę inaczej siedzi się w monachijskim Residenztheater, właśnie tak jak w scenie otwierającej powieść Jaroslava Haška, w knajpie, której bywalcy omawiają w obecności tajnego policjanta najnowszą wiadomość o śmierci „naszego Ferdynanda”. U Haška Szwejk uważa tego mało znanego pomocnika aptekarza za pierwszego wesołka. U Castorfa gospodarz mówi do monachijskiej publiczności: „Nie chcę być żadnym Prusakiem!”2. Dobrze to pasuje - ale potem wszystkim odechciewa się śmiania z tego rodzaju żartów. Szeroki i rozgałęziający się ślad zamachu w Sarajewie rozciąga się aż do naszego, z tego powodu nikczemnego świata.

\footnotetext{
2 W dialekcie bawarskim „Preiß” - pogardliwe określenie Niemców spoza Bawarii, z Królestwa Pruskiego lub w ogóle z północy.
} 
Aleksandar Denić zbudował znów na obrotowej scenie wspaniale poukładane aż po dach przestrzenie, na środku ustawił zasiek z drutu kolczastego z blaszanymi puszkami ostrzegającymi o chcących przez niego przejść - taki jak podczas I wojny światowej. Najbardziej wyrazistym elementem jest ustawiona przed nim drewniana makieta otwartej w 1914 roku berlińskiej Volksbühne, która wielokrotnie jest określana jako świątynia, a w jej wnętrzu można rozpoznać żyrandol z teatru. $Z$ lewej strony na frontonie widać małą tablicę upamiętniającą zamachowca z Sarajewa Gawriło Principa (napis cyrylicą). Właśnie ta tablica została podarowana Hitlerowi na pięćdziesiąte drugie urodziny 20 kwietnia 1941 roku jako szczególny prezent z okazji zajęcia Jugosławii.

Fotografia, na której Austriak z urodzenia ogląda to wspomnienie upadku własnego kraju, została odnaleziona w zasobach bawarskiej Staatsbibliothek i w 2013 roku opublikowana na okładce serbskiego magazynu „Vreme”, „wstrzeliła się” w proces przygotowań do upamiętnienia setnej rocznicy wybuchu I wojny światowej, a przynajmniej w jugosłowiański kompleks współczesny. Czy możliwe jest jeszcze całkowite wywrócenie do góry nogami powieści o dobrym wojaku - którego wielu zna tylko z sympatycznej wersji telewizyjnej $\mathrm{z}$ lat 70. z popularnym austriackim aktorem Fritzem Muliarem? Melduję posłusznie: bardziej się nie da!

Jest jeszcze coś. Właściwie nie chodzi o wywrócenie powieści do góry nogami, lecz o jej dotychczasową niemiecką recepcję, w której I wojna światowa zostaje ukazana jako rodzaj niewinnej, slapstickowej i absurdalnej komedii. Podstawą dla inscenizacji stał się nowy przekład Antonína Brouska, oczyszczony z lubianego przez Niemców dialektu Szwejka osadzonego w niegramatycznej praskiej niemczyźnie, która stała się popularna na dziesięciolecia za sprawą tłumaczenia Grete Reiner. Z przekładu Reiner korzystali w swoich adaptacjach najważniejsi autorzy-reżyserzy lat 20. Erwin Piscator (1928) i Bertolt Brecht (Schweyk im Zweiten Weltkrieg/Szwejk na II wojnie światowej, 1943). Później także folklorystycznie sfałszowane niemieckie ekranizacje. U Brouska od razu widać, że powieść o dyskryminowanym żołnierzu austro-węgierskiej armii dotyczy w swej istocie rozpadającej się Europy - między eksplozją na Bałkanach i rewolucją rosyjską - a nie „z urzędu durnego” hycla z praskich uliczek. To jest impuls, który pozwala zobaczyć w powieści, zaliczanej do trochę już historycznej literatury światowej, coś nowego - a dla Castorfa staje się bijącym źródłem skojarzeń z wyrastającą z I wojny światowej teraźniejszością. 1914 = 2014/16.

Aurel Manthei tworzy nowy typ Szwejka egzystencjalnie zagubionego. Szwejka, który we wszystkich przez Castorfa wywołanych burzach skojarzeń napotyka przede wszystkim silne i tajemnicze kobiety: Bibianę Beglau jako rezolutną Panią Vodičkovą, Katharinę Pichler jako jędrną, rozkoszną Katy Wendler, stojącą już w środku cesarsko-książęcych wrogości między narodami Węgierkę Etelkę (Nora Buzalka). Wreszcie w fantastycznym i zarazem najbardziej poruszającym punkcie kulminacyjnym odbywa się odrealnione, mroczne spotkanie z czarną wdową (Valery Tscheplanowa), która ukazuje się błądzącemu żołnierzowi jako anioł zwątpienia. W pięciogodzinnym spektaklu można odnaleźć i inne osie widzenia: np. rozdarcie między Wschodem i Zachodem w przeciwstawieniu Coca-Coli i Pepsi z neonami reklamowymi i automatami do napojów. Pepsi swego czasu opanowała cały blok wschodni wraz z Jugosławią. Nie posłużyło to ani lemoniadzie, ani jej amatorom. To także jest, jeśli się chce, nauka $\mathrm{z}$ historii. 


\section{Faust jako finał (2017)}

Jak wiadomo, Faust zakłada się z Mefistem o wieczność chwili spełnienia - po odmłodzeniu się napojem czarownicy i po pełnym przygód życiu przyznaje się do tego życzenia: „Trwaj, chwilo!”, krótko przed śmiercią na końcu drugiej części „dramatycznego poematu” Goethego. To zawsze było dwuznaczne. Spełnienie czy wyczerpanie? Urzeczywistnienie czy urojenie? Rozpoznanie czy deziluzja? Każda inscenizacja drugiej części musiała nie tylko określić sens zakładu, lecz także odpowiedź światopoglądową. Frank Castorf układa w swoim spektaklu wiele różnych warstw, z których jedną stanowi jego długa, faustyczna podróż jako intendanta i głównego reżysera Volksbühne, zakończona właśnie za sprawą decyzji berlińskich polityków od kultury. To mogłaby być subtelnie zaznaczona metawarstwa tej opowieści - finał samego teatru. Złożenie w grobie, kiedy Faust właściwie nie wie, czy stworzył coś wielkiego, czy też lemury zakopią go zaraz w ziemi.

Przed dwudziestu pięciu laty, krótko po zjednoczeniu Niemiec i ponownym zjednoczeniu Berlina, berlińscy politycy od kultury zawarli z nowym porządkiem ówczesnego systemu teatralnego zakład przeciw Volksbühne. Specjalnie zwołane posiedzenie ekspertów pod kierownictwem filozofa teatru Ivana Nagela zaproponowało: oddajcie ten zrujnowany teatr jakiemuś młodemu zespołowi. Albo będą po dwóch latach martwi (i będzie można tę scenę z czystym sumieniem zamknąć) - albo przezwyciężą niesprzyjające okoliczności i staną się sławni. Prowadzony przez Castorfa zespół wygrał ten zakład - aż do ostatniej chwili, która po sukcesach nie do przecenienia wyznaczających nowe trendy w Europie i mniejszych kryzysach pokazuje wspaniały triumf, daje godne miejsce $w$ historii teatru: naprawdę epicka chwila!

Faust Castorfa jest jednak daleki od autohagiografii. Chodzi o nowe odczytanie w kontekście kosmosu Castorfa z perspektywy historycznie, literacko i teatralnie ufundowanego sceptycyzmu. W dramaturgicznej strukturze historia jest opowiadana etapami, najpierw wstecz, od sceny z homunkulusem z części drugiej Fausta do „prologu w teatrze” w pierwszej części wieczoru. Dzięki temu zostaje nadany normalny kierunek wielkiej wyprawie Fausta w świat. Scena $\mathrm{z}$ homunkulusem o stworzeniu sztucznego człowieka stanowi dziś standardowy wzorzec dla teatru krytycznego w epoce biotechnologii. U Castorfa chodzi o gumową lalkę w słoju, który krąży między Doktorem Wagnerem, naiwnym uczonym, a Małgorzatą i jest prezentowany przed kamerą jak preparat z medycznej kolekcji zdeformowanych istot. Martin Wuttke jako Faust nosi do tego silikonową maskę starca i wypowiada wersy z Goethego stłumionym, gardłowym tonem starego człowieka. Castorf przywołuje w ten sposób najbardziej krytyczny moment niemieckiej recepcji Fausta, kiedy to w 1982 roku sędziwy Bernhard Minetti w spektaklu reżyserowanym przez Klausa Michaela Grübera wypowiedział prawie cały tekst jako monolog wewnętrzny człowieka wątpiącego, co zostało przez dużą część ówczesnej publiczności odebrane jako profanacja kanonicznego dramatu. To przykład, jak Castorf pracuje również z pamięcią historii teatru w swoim spektaklu. Kiedy maska zostaje zdjęta, Wuttke pokazuje zimnego, cynicznego, cierpiącego Fausta, który w małym stopniu jest Panem Zdarzeń i nie znajduje w kumpelskim Mefiście Marca Hosemanna metafizycznego przeciwnika. W metodzie Castorfa tak czy owak w niewielkim wymiarze chodzi o psychologiczną interpretację postaci, ale jak najbardziej o ich znaczenie w ramach konkretnych kontekstów i referencji. 
W retrospekcji „prologu w teatrze” nadchodzi moment satyrycznego ujęcia realnej sytuacji Volksbühne. Alexander Scheer gra wiele obiecującego dyrektora teatru mówiącego z flamandzkim akcentem typowym dla przyszłego belgijskiego dyrektora Chrisa Dercona, w końcu Wuttke rozbija mu na głowie kufel piwa - co w gorących do dziś debatach wokół powołania Dercona na szefa Volksbühne naprawdę może się wydarzyć berlińską nocą. W amplitudzie między głęboką nową interpretacją a ostrym widzeniem rzeczywistości jest to moment wychylenia ku kabaretowi.

Decydujący jest ruch skojarzeń w poszczególnych scenach, które zabierają widza w podróż w kolonialną historię Francji - do Algierii. Druga część Fausta, obejmująca czasy od średniowiecza, z motywami antycznymi, i przez to prowadząca do przemyślenia negatywnych i postępowych skutków rewolucji francuskiej, powstała na początku ery kolonialnej. Faust Castorfa zanurza się w finale w otchłani ludzkiego zepsucia i odnajduje się na mentalnej pustyni wojny w Algierii, cytując Frantza Fanona.

Scena obrotowa Alexandra Denicia stanowi tutaj wyrafinowaną konstrukcję architektoniczną, która stwarza we wnętrzu baru plan filmu transmitowanego na żywo za pomocą dwóch kamer. Na zewnątrz ta konstrukcja może być odczytywana jako fryz wspólczesnej krainy umarłych: fasada klubu nocnego „L'enfer” (Piekło), wejście do stacji metra „Stalingrad”, plakaty z horrorów filmowych - w całości swego rodzaju sarkofag kryjący ruiny najnowszej historii. Najbardziej znaczący węzeł stanowi tu włączenie odgrywanej przez Valery Tscheplanową (w kontrze do tradycji - wyprostowanej i antagonistycznie nastawionej wobec Fausta) Małgorzaty w kontekst filmu Bitwa o Algier z 1966 roku. Właśnie odkryty dla kina krytycznego film włoskiego reżysera Gilles’a Pontecorvo został nakręcony z naturszczykami w prawdziwej fortecy Kasbah w Algierze jako półdokumentalny dramat o antykolonialnym powstaniu, w którym kilka niepozornych Małgorzat w europejskich strojach podkłada bomby Faustom w barach, aby wysadzić w powietrze francuskich kolonizatorów. W ten sposób Castorf wprowadza do przedstawienia problem politycznego terroru, historycznie uzasadniony i uwolniony z kontekstu zwyczajnego paktu z Mefistem. W przypominającym do złudzenia oryginalny wagonie paryskiego metra ustawionym w foyer teatru francuski raper Abdoul Kader Traoré cytuje do kamery Fugę śmierci Paula Celana o tym, że w niebie jest kopany grób.

Traoré, kolorowy artysta, akcentuje poza tym jeszcze jeden ważny aspekt w sporze o Volksbühne. Według krytyków rzekomo ta scena nie jest wystarczająco międzynarodowa i za bardzo skupiona na historii Wschodu, z czym należałoby w końcu zerwać - w duchu zachodnioniemieckiego neoliberalizmu. Ale to Castorf jako pierwszy pracował z międzynarodowym zespołem i kazał aktorom występować w językach obcych. Jego Faust jest świetnym przykładem, jak auteur-director wpisuje rdzennie niemiecki dramat w kontrowersyjne konteksty międzynarodowe. Widać to także w obrazie końcowym, kiedy Martin Wuttke jeździ w kółko na dziecięcym, trójkołowym rowerku, dając obraz totalnej regresji, a Mefisto wciąż bije go algierską flagą po głowie albo burżuazyjnym cylindrze. Projekt naprawy świata w tej interpretacji nawiązującej do filozofii historii Heinera Müllera poniósł żałosną klęskę. 


\section{Bibliografia}

Balitzki, Jürgen 1995. Castorf, der Eisenhändler. Theater zwischen Kartoffelsalat und Stahlgewitter. Berlin: Ch. Links Verlag.

Eilers, Dorte Lena, Thomas Irmer, Harald Müller (red.) 2016. Castorf. Arbeitsbuch 2016. Berlin: Theater der Zeit.

Irmer, Thomas, Harald Müller (red.) 2003. Zehn Jahre Volksbühne. Intendanz Frank Castorf, Berlin: Theater der Zeit.

Irmer, Thomas, Matthias Schmidt (red.) 2003. Die Bühnenrepublik. Theater in der DDR, Berlin: Alexander Verlag.

Raddatz, Frank (red.) 2016. Republik Castorf, Berlin: Alexander Verlag. 